\title{
Hin óttablandna virðing: Um kennsluhætti og viðteknar hefðir í tónlistarnámi
}

\begin{abstract}
Helga Rut Guðmundsdóttir og Freyja Gunnlaugsdóttir
Abstract

- Um höfunda

About the authors

Heimildir

Í pessari grein verður fjallað um viðtekna kennsluhætti í tónlistarnámi, ekki síst á efri skólastigum, og litið til fræðilegra skrifa um petta efni á sviði tónlistarfræða og tónlistarmenntunar. Horft verður til kennsluhátta og samskipta í tónlistarmenntun á efri stigum og skoðað hvaða markmið liggja til grundvallar tónlistarnámi. Rýnt verður í fræðigreinar um áhrif valdaójafnvægis og viðtekinna kennsluhátta í tónlistarnámi á tónlistarnemendur og mögulegar afleiðingar fyrir atvinnutónlistarmenn og par með tónlistarlífið í heild. Um er að ræða yfirlitsgrein par sem rýnt er í ólíkar rannsóknir um petta efni á sviði tónlistarfræða og menntunarfræða tónlistar.
\end{abstract}

Leitað verður í smiðju fræðimanna á sviði heimspeki tónlistarmenntunar sem og almennra menntunarfræða varðandi framtíðarsýn fyrir tónlistarmenntun sem geti alið af sér heilsteypt, skapandi tónlistarfólk og heilbrigt tónlistarlíf, samfélaginu og einstaklingum til heilla.

Fórnarkostnaður af neikvæðri reynslu úr tónlistarnámi getur verið umtalsverður og haft alvarlegar afleiðingar, bæði fyrir einstaklinga og tónlistarlífið í heild. Margir tónlistarmenn pjást af vinnutengdum kvillum, bæði andlegum og líkamlegum. Sviðsskrekkur, kvíði og álag er viðvarandi vandamál hjá mörgum tónlistarmönnum og lyfjanotkun er algeng í tónlistarlífinu.

Í greininni er bent á mikilvægi pess að tónlistarkennarar og skólakerfið spyrji sig hvort hlutverk peirra sé að mennta nemendur til að ganga inn í tiltekna hefð eða hvort leitast eigi við að mennta sjálfstæða einstaklinga sem geti haft áhrif á viðteknar hefðir og unnið að pví að móta nýtt og betra samfélag. Nauðsynleg frampróun krefst pekkingar á pví sem á undan er gengið og ígrundunar á peim rannsóknum sem farið hafa fram á sviði tónlistarmenntunar. Markmið pessarar greinar er að varpa ljósi á ríkjandi starfshætti og fyrirkomulag tónlistarkennslu sem lítil umræða hefur verið um og hefur hingað til lítið verið gagnrýnt.

Efnisorð: Tónlistarmenntun, tónlistarkennsla, tónlistarnám, einkakennsla, valdajafnvægi, skólastefna

\section{Inngangur}

Í pessari grein er fjallað um hljóðfærakennslu¹ á efri stigum tónlistarnáms. Viðteknir kennsluhættir og samskipti nemenda og kennara eru meginviðfangsefni greinarinnar. Um er að ræða yfirlitsgrein par sem rýnt er í rannsóknir og skrif á sviði tónlistarfræða og menntunarfræða tónlistar. Hugmyndafræðilegur grunnur peirra skrifa sem rýnt er í á sviði tónlistarmenntunar byggist á nálgun gagnrýninna kenninga (e. critical theory) sem eiga rætur sínar í nálgun Dewey (1922) og Freire 
(1998) og sjónarhorni peirra á menntaumbætur. Kveikjan að greininni á rætur að rekja í áhuga á að móta gott skólasamfélag par sem nemendur og kennarar geta vaxið sem manneskjur og listamenn. Par er ekki síst mikilvægt að lærdómsferlið sjálft sé innihaldsríkt og ánægjulegt og að komið sé til móts við parfir og áhuga nemenda. Par að baki liggur einnig hugsun um hvort hægt sé með bættum kennsluháttum í tónlistarnámi að stuðla að góðu tónlistarlífi, betri samskiptum og líðan peirra sem starfa við tónlistarflutning, eða eins og tónlistarfræðingurinn Lucy Green fjallaði um í bókinni Music Education as Critical Theory and Practice; að gagnrýnum kenningum sé beitt til að greina og útskýra í peim tilgangi að bæta starfshætti sem starfendur sjálfir eru mögulega ekki meðvitaðir um (Green, 2017, bls. ix).

Í upphafi greinarinnar er fjallað um einkakennslufyrirkomulagið og hvernig pað próaðist sem burðarstólpi í tónlistarnámi. Umræðan er par næst tengd við tónlistarlífið og ýmis vandamál sem atvinnutónlistarfólk stendur frammi fyrir. Leitast er við að varpa ljósi á pætti sem geta staðið heilbrigðu tónlistarlífi fyrir prifum og rætt hvaða áhrif kennsluhættir í tónlistarnámi geta haft á líf og starf tónlistarfólks. Í framhaldi er fjallað um valdaójafnvægi sem skapast getur í tónlistarnámi. Athyglinni er pá beint að menningu sem snýr að virðingu, samskiptum, fullkomnunaráráttu og fleiri páttum sem geta haft neikvæð áhrif á nám og proska tónlistarnema. Pá er kastljósinu ekki síst beint að kennaranum sjálfum og kennsluháttum í tónlistarnámi. Að lokum er skoðað hvernig hugmyndir um mannkostamenntun og lærdómssamfélag gætu nýst til pess að byggja upp heilbrigt námsumhverfi fyrir tónlistarnema.

Fagleg umræða um tónlistarmenntun á Íslandi hefur verið af skornum skammti og lítið ritað um álitamál á sviði tónlistarmenntunar sem hafa verið áberandi á alpjóðlegum vettvangi síðastliðna hálfa öld. Í pessari grein er vísað til nokkurra grundvallarrita í pví skyni að varpa ljósi á gagnrýna menntaumræðu á sviði tónlistar en er pó engan veginn tæmandi úttekt á peirri umræðu. Pað er von höfunda að greinin veki áhugasama um tónlistarmenntun til vitundar um málefni sem varða tónlistarmenntun og samfélag en megi jafnframt vera hvatning til frekari umræðu um hlutverk menntakerfisins í tónlistarlífi Îslendinga og hlutverk tónlistar í íslensku menntakerfi.

\section{Sérkenni tónlistarmenntunar}

Tónlistarmenntun er á ýmsan hátt frábrugðin annarri menntun sem einstaklingum stendur til boða í nútímasamfélagi. Tónlistarkennsla fer að miklu leyti fram í formi einkakennslu par sem nemendur sækja tíma hjá kennurum sínum vikulega og á efri stigum tónlistarnáms eru kennararnir yfirleitt listamenn sem hafa afburðakunnáttu á sitt hljóðfæri (Daniel og Parkes, 2017). Pessu forna kennsluformi meistara og sveina (e. masters and apprentices) er að vísu fylgt í tónlistarskólum á öllum skólastigum og fer bróðurpartur tónlistarkennslu fram á pennan hátt (Allsup, 2016). Allt bendir til að pess að einkatímar séu fremur regla en undantekning í íslenskum tónlistarskólum. Samband nemanda og kennara er oft náið í slíku námsfyrirkomulagi og tónlistarkennari getur haft mikil áhrif á nemendur sína, ekki síst pegar um er að ræða virta listamenn sem nemendur bera mikla virðingu fyrir.

\section{Kostir einkakennslu}

Einkakennsluformið í hljóðfærakennslu hefur tíðkast um aldir en varð mjög vinsælt á 19. öld pegar listamenn á borð við Liszt og Paganini urðu eftirsóttir kennarar. Peir voru dáðir af nemendum sínum sem fylgdu peim líkt og um átrúnaðargoð væri að ræða. Kennarinn varð miðpunktur kennslunnar og nemendurnir báru óttablandna virðingu fyrir meistara sínum. Pó skal taka fram að pessar stórstjörnur 19. aldar kenndu reyndar oft líka í hóptímum, eða samkvæmt svokölluðu „masterclass“-formi par sem allur bekkurinn var viðstaddur tímana. Á sama tíma varð alsiða að börn, og pá sérstaklega stúlkur af yfirstétt, nytu tónlistarkennslu í einkatímum, en litið var á pað sem hluta af almennri menntun peirra. Petta smitaðist svo út til millistéttarinnar pegar leið á öldina og algengt að píanó væri til staðar á betri heimilum (Daniel og Parkes, 2017; Hallam, 1998). 
Pegar best lætur gæti einkakennsluformið verið besta mögulega form menntunar par sem athygli kennarans er aðeins á einum nemanda í einu (Hallam, 1998). Í tónlistarnámi er viðfangsefni kennslustundanna oft persónulegt, túlkun verkanna snýst um sammannlegar tilfinningar og um að ná djúpum skilningi á merkingu tónlistarinnar. Par er mikilvægt að öðlast skilning á tímanum sem verkin voru samin á og að nemendur geti sett sig í spor fyrri kynslóða. Til pess að gera flutninginn trúverðugan purfa peir að gera pær tilfinningar sem tónverkið felur í sér að sínum en pað krefst sjálfsskoðunar og tilfinningadýptar af hálfu flytjandans. Markmiðið er að nemandinn öðlist áðurnefndan skilning á tónlistinni og geti flutt hana af tilfinningalegri dýpt á sama tíma og hann verður að ná eins fullkomnu valdi á sínu hljóðfæri og mögulegt er. Tæknileg færni gerir nemandann smám saman færari um að nota hljóðfæri sitt eða rödd sem verkfæri til pess að túlka pá sögu og tilfinningar sem tónlistin ber í sér pannig að pað hreyfi við áheyrendum. Petta ferli getur verið stórkostlegt, en á sama tíma kostað mikil átök og protlausa vinnu (Davidson og Jordan, 2007; Hallam, 1998).

Markmið kennarans verður oft bæði að fá nemandann til að ná eins tæknilegri fullkomnun í faginu og hægt er og fara út fyrir pægindarammann eða jafnvel út á bjargbrúnina við túlkun verkanna. Petta kennsluform býður upp á mjög einstaklingsmiðaða kennslu par sem tækifæri er til að klæðskerasníða námið að pörfum hvers nemanda. Prátt fyrir petta eru ýmis vandamál sem rekja má til einkakennsluformsins, rótgróinna viðhorfa í tónlistarlífinu og valdaójafnvægis sem skapast getur við pessar aðstæður (Davidson og Jordan, 2007; Persson, 1994).

Við nánari athugun kemur íljós að fórnarkostnaður af neikvæðri reynslu úr tónlistarnámi getur verið umtalsverður og haft alvarlegar afleiðingar, bæði fyrir einstaklinga og tónlistarlífið í heild. Margir tónlistarmenn pjást af vinnutengdum kvillum, bæði andlegum og líkamlegum. Sviðsskrekkur, kvíði og álag er viðvarandi vandamál hjá mörgum tónlistarmönnum og lyfjanotkun er orðin algeng í tónlistarlífinu (Kenny, 2006; Kenny og Ackermann, 2015; Yoshie o.fl., 2009).

\section{Kvillar í tónlistarlífinu}

Til að varpa skýrara ljósi á umhverfi og aðstæður tónlistarmanna verður hér fjallað um tónlistarlífið og vandamál sem tónlistarmenn standa frammi fyrir. Pessi vandamál má rekja til margra ólíkra pátta sem eiga sér samfélagslegar, sálfræðilegar og tilvistarlegar rætur. Ástæðan fyrir pví að hér er fjallað um pessa kvilla í tónlistarlífinu er að varpa ljósi á hve mikilvægt pað er fyrir kennara og menntastofnanir að vinna gegn pessari próun og undirbúa nemendur sem best undir að takast á við pessa pætti.

Ófáir tónlistarmenn pjást af framkomukvíða sem getur litað daglegt líf peirra sem og tónlistarflutning. Jafnframt purfa margir að glíma við líkamleg meiðsli sem má rekja til álags í tengslum við hljóðfæraleik og protlausar æfingar. Ótal rannsóknir sýna fram á alvarleika framkomukvíða og pau áhrif sem hann getur haft (Gleitman, Fridlund og Reisberg, 2003; Hays og Brown, 2004; Ingunn Jónsdóttir, 2015; Steptoe, 2001). Stór alpjóðleg rannsókn sem gerð var á hljóðfæraleikurum úr 56 sinfóníuhljómsveitum sýndi fram að $70 \%$ peirra pjáðust af framkomukvíða, par af voru $16 \%$ sem sögðust pjást stöðugt af honum eða oftar en einu sinni í viku (Steptoe, 2001). Önnur stór eldri rannsókn sýndi fram á að $82 \%$ tónlistarmanna purftu að kljást við heilsufarsleg vandamál sem rekja mátti til tónlistariðkunar (Lockwood, 1989).

Rannsóknir hafa sýnt fram á að framkomukvíða megi rekja til ólíkra pátta og hluti peirra telst náttúruleg viðbrögð líkamans við álagi, en félagslegir pættir, líkt og umhverfi, samskipti og viðhorf, hafa ekki síður mikil áhrif. Par spilar inn í hart samkeppnisumhverfi allt frá námsárum, óreglulegir vinnutímar, fjárhagslegt óöryggi, rótgróin viðhorf og æfingaálag (Gleitman o.fl., 2003; Hays og Brown, 2004; Ingunn Jónsdóttir, 2015). Í rannsókn par sem 130 atvinnugreinar voru skoðaðar reyndust tónlistarmenn vera meðal peirra fimm atvinnugreina sem líklegastar voru til pess að próa með sér andlega kvilla (e. mental disorder) (Brodsky, 1996). Í annarri rannsókn par sem ólíkar atvinnugreinar voru bornar saman komu tónlistarmenn verst út pegar skoðað var hvaða starfsstéttir voru líklegastar 
til pess að pjást af streitu, örmögnun, svefntruflunum, háum blóðprýstingi, höfuðverkjum og fleiri líkamlegum kvillum sem rekja mátti til álags í starfi (Kivimaki og Jokinen, 1994).

Í rannsókn sem Ingunn Jónsdóttir gerði árið 2010 sýndi hún fram á alvarleika framkomukvîða á íslenska tónlistarmenn, en par kom fram að yfir helmingur Sinfóníuhljómsveitar Íslands hafði notað beta-blokkara við tónlistarflutning og að $14 \%$ peirra atvinnutónlistarmanna sem tóku pátt í rannsókninni notuðu lyfin að staðaldri við tónlistarflutning. Beta-blokkarar eru flokkur lyfja sem eiga pað sameiginlegt að hindra áhrif adrenalíns og noradrenalíns á notanda peirra. Lyfin hafa áhrif á hjartsláttartíðni og skjálfta, en eru oft notuð til meðhöndlunar á háprýstingi, kransæðasjúkdómum, hjartsláttartruflunum og öðrum hjartasjúkdómum (Ingunn Jónsdóttir, 2010). Margir tónlistarmenn kljást enn fremur við líkamleg meiðsli sem rekja má til tónlistariðkunar og æfingaálags. Í ástralskri rannsókn frá 2012 sem allar sinfóníuhljómsveitir landsins tóku pátt í kom í ljós að 84\% hljóðfæraleikaranna höfðu glímt við meiðsli eða langtímaverki sem rekja mátti til hljóðfæraleiks, $50 \%$ aðspurðra var að kljást við kvillana á peim tíma sem rannsóknin var gerð og innan við 50\% sögðust hafa hlotið bata eftir slík meiðsli (Ackerman, o.fl., 2012).

Kári Árnason, Árni Árnason og Kristín Briem gerðu rannsókn á íslenskum tónlistarnemum árið 2014 og sýndu niðurstöður peirra fram á að 62\% nemenda á efri stigum tónlistarnáms voru að kljást við meiðsli eða verki sem tengdust hljóðfæraleik, en $40 \%$ á peim tíma pegar rannsóknin var gerð (Kári Árnason o.fl., 2014). Sambærileg rannsókn, sem gerð var á 330 bandarískum háskólanemum, leiddi í ljós enn alvarlegri stöðu, en par sögðust 79\% nemenda stríða við afleiðingar meiðsla og verki vegna hljóðfæraleiks (Brandfonbrener, 2009). Tölurnar eru sláandi, sérstaklega pegar litið er til pess að hér er um ungt og almennt hraust fólk að ræða. Allar pessar rannsóknir og margar fleiri gefa vísbendingar um að ekki sé nógu útbreidd meðvitund um mikilvægi pess að takast á við pað líkamlega og andlega álag sem fylgir hljóðfæraleik nógu snemma og vinna gegn pví á fyrri stigum tónlistarnáms. Pessar uggvænlegu niðurstöður gefa tilefni til frekari rannsókna á pessu sviði en í pessari grein beinist athyglin fyrst og fremst að tónlistarmenntuninni og hvað menntastofnanir og tónlistarkennarar geta gert til pess að vinna gegn pessari skaðvænlegu menningu og bæta samskipti og vinnuanda í tónlistarlífinu.

\section{Hin óttablandna virðing}

Fjölmargir fræðimenn á sviði kennslufræði tónlistar hafa gert valdaójafnvægi í einkatímum í tónlist að viðfangsefni og pær neikvæðu afleiðingar sem pað hefur á einstaklinga og tónlistarlífið í heild (Allsup, 2016; Bowman, 2010; Carey og Grant, 2015; Christophersen, 2013; Daniel og Parkes, 2017; Elliott og Silverman, 2015; Gaunt, 2011; Jorgensen, 2003). Petta er áhyggjuefni fyrir menntastofnanir í tónlist, tónlistarlífið og samfélagið í heild. Hér á landi hefur skort á umræðu um viðtekna kennsluhætti í tónlistarnámi en pó ber að minnast á meistararitgerð Póru Einarsdóttur við Listaháskóla Íslands (Póra Einarsdóttir, 2015). Í ritgerðinni fjallar Póra um meint valdaójafnvægi í söngkennslu og aðferðir söngkennara sem sveipaðar eru dulúð par sem nemandanum er gert að setja allt traust sitt á einn aðila. Póra bendir á galla pessa fyrirkomulags og greinir frá starfendarannsókn sem hún gerði með pað að markmiði að breyta viðteknum kennsluháttum „pannig að nemandanum sé mætt á jafningjagrundvelli, auka gagnsæi og ekki síst stuðla að frumkvæði og sjálfstæði nemenda“ (Póra Einarsdóttir, 2015, bls. 12).

Í bók sinni Remixing the Classroom frá árinu 2016 gerir Randall Everett Allsup að umtalsefni hversu algengt sé að harka og grimmd viðgangist í tónlistarnámi, og pá sérstaklega í einkatímum í tónlist (Allsup, 2016). Líkt og fleiri fræðimenn bendir hann á að valdaójafnvægið milli kennara og nemanda geti haft mjög neikvæð áhrif á nemandann ef kennari nýtir sér pað vald sem hann hefur yfir nemandanum á óviðeigandi hátt (Allsup, 2016; Bowman, 2010; Elliott og Silverman, 2015; Gaunt, 2011).

Flestir peir sem hafa stundað tónlistarnám pekkja stranga kennarann sem talar til nemendanna á niðurlægjandi hátt, og vísar pá oft til pess að nemandinn sé ekki nægilega músíkalskur og jafnvel 
ekki verðugur pess að fást við meistaraverk tónlistarsögunnar. Allsup vill meina að með pess háttar kennsluaðferðum séu nemendur beittir ofbeldi og að pær séu til pess fallnar að drepa niður áhuga peirra og ást á tónlist, jafnvel pótt pær geti líka leitt til pess að nemendur æfi sig meira og mæti betur undirbúnir í tónlistartíma á pví augnabliki. Í pess konar lærlings-meistara-sambandi leiki óttinn lykilhlutverk og pað geti ekki leitt til góðs pegar til lengri tíma er litið. Jafnframt fjallar hann um hve sorglegt pað er að ofbeldi af pessu tagi sé oft dulbúið sem óttablandin virðing fyrir tónlistinni og oftar en ekki sveipað dulúð, pað er að ekki allir hafi aðgang að undraheimi listarinnar og pví séu pað forréttindi að eiga í samskiptum við pann snilling sem kennarinn hljóti að vera. Allsup notar pá líkingu að nemendur rekist ítrekað á hlið og knýi dyra en einungis örfáum peirra, p.e. afburðanemendum, sé hleypt í gegn og fái að njóta listarinnar. Hann gengur svo langt að segja að háttalag af pessu tagi í kennslu sé aðför að lýðræði, en nánar verður vikið að pví síðar. Einnig færir hann rök fyrir pví að mannlegur fórnarkostnaður sem af pví hljótist sé allt of hár. Of margir nemendur sitji eftir í sárum og margir hætti að iðka tónlist vegna neikvæðra samskipta í tónlistarnámi. Hann bendir jafnframt á að pessi mannlegi fórnarkostnaður hafi slæm áhrif á tónlistarlífið í heild par sem of margir eigi mjög neikvæða reynslu að baki úr sinni skólagöngu sem taki langan tíma að vinna úr (Allsup, 2016).

Í grein frá 2011 fjallar Gaunt um pá óttablöndnu virðingu sem tónlistarnemendur bera gjarnan fyrir kennurum sínum og hvernig peir fara að líkja eftir peim síðarnefndu, bæði í tónlistarlegu tilliti en líka í viðhorfum og hegðun. Î pessu samhengi fjallar hún einnig um samband doktorsnema og leiðbeinenda peirra, vandamálið er pví ekki aðeins tengt tónlistarkennslu heldur tengist einnig félagslegri formgerð. Pó má færa rök fyrir pví að kúgandi valdastrúktúr komi sérstaklega illa niður á tónlistarnemendum, ekki síst vegna aðdáunar á sjálfu viðfangsefninu, tónlistinni sjálfri (Gaunt, 2011).

Hún hvetur kennara pví til pess að vanmeta ekki pau áhrif sem peir geta haft á nemendur sína og koma fram við pá af virðingu og á jafningjagrundvelli. Hún vekur athygli á pví valdaójafnvægi sem skapast getur í tónlistarkennslu og hvernig pað verður til pess að nemendur eiga erfitt með eðlileg samskipti við kennara sína eða með að skipta um kennara pegar pess gerist pörf. Niðurstöður rannsóknar hennar leiddu í ljós að nemendur sem flæktir eru í pess konar valdasamband við kennara sína eiga erfiðara með að ná listrænum proska, próa sinn persónulega stíl og að fóta sig í tónlistarlífinu (Gaunt, 2011).

Elisa Kupers og fleiri fjalla um í grein frá 2015 hversu mikilvægt er í tónlistarkennslu að ýta undir sjálfstæð vinnubrögð og frumkvæði nemenda. Kennslan ætti, að peirra dómi, að miða að pví að mennta sterka og sjálfstæða listamenn sem pora að fara eigin leiðir. Rannsókn peirra sýndi fram á að peir nemendur sem höfðu hlotið pess háttar stuðning frá kennurum sínum voru mun líklegri til pess að verða atvinnumenn í tónlist og njóta velgengni í starfi heldur en peir nemendur sem höfðu verið hjá kennurum sem höfðu of mikið vald yfir peim (Kupers o.fl., 2015).

Í stað pess að niðurlægja nemendur og drepa niður áhuga peirra og ást á tónlist með pví að vilja hafa algjöra stjórn á peim ætti pað að vera meginmarkmið tónlistarkennarans að varðveita og viðhalda áhuga og ást nemandans á listinni. Tónlistin er svo samofin mennskunni og mannlegum tilfinningum að við tónlistarkennslu er mikilvægt að huga einnig að peirri hlið kennslunnar, hvernig hún getur styrkt nemendurna sem manneskjur og pátttakendur $i$ að byggja upp gott og heilbrigt samfélag (Allsup, 2015; Elliott og Silverman, 2015; Jorgensen, 2003, 2008).

\section{Leitin að fullkomnun}

Til að kenna hljóðfæraleik eða söng á efri stigum parf kennari að búa yfir góðri færni í sínu fagi. Kennarastöður afpessu tagi eru eftirsóttar í tónlistarheiminum. Kennslan fer ávallt fram í einkatímum, nemandinn ber oft mikla virðingu fyrir kennara sínum og hefur að markmiði að ná fullkomnun á hljóðfæri sitt. Afleiðingarnar af pessari nálgun eru oft pær að flestum, að örfáum afburðanemendum frátöldum, mistekst að ná fullkomnun og fyrir vikið upplifa peir tónlistarnámið með neikvæðum hætti (Allsup, 2016). Oft gleymist að hugsa um hverju kennslan skilar, bæði einstaklingunum og 
samfélaginu. Pví er mikilvægt að tónlistarkennarar staldri við og hugsi um hvernig tónlistarfólk peir vilji mennta og hvers kyns tónlistarlíf peir vilji stuðla að. Peir purfa að velta pví fyrir sér hvaða menningu peir vilji ýta undir í tónlistariðkun og samskiptum manna á milli (Allsup, 2016; Gaunt, 2011; Jorgensen, 2003).

Petta „allt eða ekkert“-hugarfar er ekki óalgengt í tónlistarháskólum eða á efri stigum tónlistarmenntunar, og pað smitar út frá sér um allt skólakerfið. Allsup færir rök fyrir pví að í hugarfari, sem felur í sér sífellda leit að fullkomnun, sé falin kapítalísk hugsun par sem aðeins afburðanemendur séu pess verðugir að njóta galdurs tónlistarinnar. Algeng rök með pví viðhorfi eru að pessi fullkomnunarhyggja sé nauðsynleg til að undirbúa nemendur undir harðan heim tónlistarlífsins, pað sé jú aðeins einn sem vinni í prufuspili eða samkeppni (Allsup, 2016). Pess konar pröng og útilokandi nálgun á menntun vill John Dewey meina að snúist upp í andhverfu sína og geti alls ekki talist ásættanleg menntun. Aðferð eða afurð er pá farin að stýra kennsluháttum á kostnað menntunarinnar sjálfrar (Dewey, 1922). Hætta er á að slíkt hugarfar sé til pess fallið að stórum hluta nemenda líði eins og peir séu misheppnaðir og ef hugsað er um heildina hefur pað í för með sér vanlíðan og slæma strauma og samskipti út í tónlistarlífið og samfélagið. Allsup dregur pví pá ályktun að í breyttu tónlistarumhverfi purfi nemendur að fá víðtækari menntun og pjálfun í að bregðast við ólíkum aðstæðum í síbreytilegu tónlistarlífi og óvissri framtíð. Рað að pjálfa nemendur einungis í pví að leika á sem fullkomnastan hátt á hljóðfæri geti verið hamlandi og staðið skapandi hugsun fyrir prifum. Sú aðferð sé pví alls ekki til pess fallin að nemendur öðlist viðeigandi menntun í skilningi Deweys (1922) eða nái að fóta sig í síbreytilegu umhverfi tónlistarlífsins (Allsup, 2016).

Eins mikilvægt og pað er að pekkja hefðina, söguna og öðlast frábæra tækni pá getur hefðin stundum verið til trafala, ekki síst pegar um er að ræða hefðir í tónlistarmenntun og hvaða nálgun er viðtekin í hljóðfærakennslu. Afburðanemandi sem hefur frábæra tækni á hljóðfæri sínu er hugsanlega ekki vel undirbúinn til að takast á við atvinnumennsku pví að menntun hans hefur stundum verið of einhæf og aðrir pættir vanræktir en sá að ná afburðahæfni á hljóðfærið. Pað hefur sýnt sig að nemendur sem aldir eru upp við of mikla fullkomnunaráráttu eiga oft erfitt með að stíga út fyrir pægindarammann og gera eitthvað sem ekki samræmist hefðinni eða að fóta sig í óvæntum aðstæðum (Allsup, 2016; Hausman, 2009; Jorgensen, 2003).

Kennari sem hugsar einungis um að pjálfa hljóðfæraleikara pannig að peir nái frábærum árangri gleymir stundum að hlúa jafnt að öllum nemendum. Fyrir nemanda sem ætlar sér ekki endilega að verða tónlistarmaður getur tónlistarmenntunin engu að síður skilað miklu og verið mikilvægur hluti af hans menntun. Tónlistarmenntun ætti að skila sér í gleði við tónlistariðkun, sama á hvaða getustigi nemandinn er, að ógleymdum peim ótal páttum sem tónlistarnám getur stutt við og pjálfað í proska og námi manneskjunnar, en fjöldi rannsókna sýnir fram á hvernig tónlistarnám hefur jákvæð áhrifá annað nám og virkni heilans (Elliott og Silverman, 2015; Jorgensen, 2003; Margulis, 2018). Til pess að menntun allra nemenda sé eins innihaldsrík og best verður á kosið er mikilvægt að mæta hverjum nemanda á hans forsendum og laga námið að hans pörfum og áhugasviði. Einkatímaformið ætti að vera vel til pess fallið og felur raunar í sér einstakt tækifæri til pess að laga námið að hverjum og einum nemanda.

Mikilvægt er að tónlistarkennarar spyrji sig hvort hlutverk peirra sé að mennta nemendur til að ganga inn í tiltekna hefð og passa inn í samfélagið eins og pað er núna eða hvort peir eigi að leitast við að mennta sjálfstæða einstaklinga sem geti haft eigin áhrif á hefðina og unnið að pví að móta nýtt og betra samfélag (Hausman, 2009). Samkvæmt Allsup byggist góð menntun á vel skilgreindri hefð en ýtir á sama tíma undir nýsköpun og pekkingarsköpun. Pví ættu tónlistarkennarar að vinna að pví að fjölga möguleikum fyrir nemendur, ala pá upp í víðsýni og pekkingarsköpun í stað pess að miðla pekkingunni einungis milli kynslóða pannig að hún gangi óbreytt milli peirra (Allsup, 2016). 


\section{Bestu tónlistarkennararnir}

Nú sem fyrr sækjast tónlistarskólar og tónlistarháskólar eftir frægum kennurum sem hafa mikla sviðsreynslu og afburða hljóðfærakunnáttu. Pegar kennarar eru ráðnir til pess að kenna hljóðfæraog söngnemendum á efri stigum ræður fyrst og fremst listrænn ferill kennaranna og færni peirra á hljóðfæri stöðuveitingum fremur en kennslufræðimenntun og fræðileg pekking kennaranna á faginu (Burwell, 2013; Daniel og Parkes, 2017). Rannsóknir undanfarinna ára sýna fram á að í raun og veru hefur mikill minnihluti kennara á efri skólastigum lokið formlegri kennslufræðimenntun. Par sem kennslan er „maður á mann“ og fer fram fyrir luktum dyrum er oft erfitt að bera kennsl á hvað ber raunverulegan árangur í hljóðfærakennslu. Pó sýna rannsóknir fram á að krafa um gagnsæi og viðurkenndar kennsluaðferðir á öllum sviðum verður æ sterkari í samfélaginu (Burwell, 2013; Carey og Grant, 2015; Daniel og Parkes, 2017). Í rannsókn frá árinu 2017 skoðuðu Daniel og Parkes pá áhrifapætti sem hafa hvað sterkust áhrif á kennsluaðferðir hljóðfærakennara á efri stigum. Niðurstöðurnar voru afgerandi og leiddu í ljós að áhrifamesti pátturinn var hvernig tónlistarnámi peirra hafði verið háttað: Kennarar voru með öðrum orðum líklegir til pess að líkja að miklu leyti eftir eigin kennurum. Annar páttur sem hafði mikil áhrif var peirra eigin starfsreynsla, pað er sviðsreynsla. $\mathrm{Pa}$ var sláandi að einungis peir kennarar sem höfðu lært kennslufræði nefndu pað sem áhrifapátt á sína kennslu og einungis peir sem höfðu doktorspróf í kennslufræði (2 einstaklingar) tilgreindu pað sem mikilvægasta páttinn í mótun eigin kennsluaðferða. Rannsóknin sýndi pví fram á að kennarar treystu mikið á eigin fyrirmyndir og reynslu frekar en rannsóknir á sviði kennslufræði Í sömu rannsókn kom fram að sýnikennsla lék oft stórt hlutverk í kennslunni, par sem kennari lék hendingu á hljóðfærið og nemandi hermdi eftir (Daniel og Parkes, 2017).

Af pessu má ráða að hefðir gegni stóru hlutverki í hljóðfærakennslu og að pekkingin gangi milli kynslóða nokkuð óbreytt, en einnig að kennsluaðferðir breytist lítið áratugum saman. Pað að kennarar leiti að svo miklu leyti í reynslu af eigin skólagöngu gerir pað einnig að verkum að ákveðnum valdakerfum og fastmótuðum hefðum frá fyrri tíð er viðhaldið í tónlistarkennslu. Pað er auðvitað að mörgu leyti jákvætt að ákveðin pekking gangi á pennan hátt á milli kynslóða en pað myndi styrkja menntunina til muna ef kennarar hefðu aukinn skilning á kennslufræði í hljóðfærakennslu og væru vel heima í rannsóknum á sviði menntunarfræða (Carey og Grant, 2015; Daniel og Parkes, 2017).

\section{Hvað einkennir góðan tónlistarkennara?}

Stöldrum aðeins við og hugsum um hvaða ábyrgð er lögðá hendur kennurum í lýðræðissamfélagi. Pær væntingar eru gerðar til kennara að hann veiti nemanda sínum staðgóða menntun sem í framtíðinni á að tryggja að hann njóti velgengni. Treyst er á skólana að peir ali upp ábyrga og virka borgara í lýðræðissamfélagi (Dewey, 1922). Kennarinn á enn fremur að búa nemandann undir atvinnulífið og fullorðinsárin (Allsup, 2016; Jorgensen, 2003).

Pegar við leiðum hugann að hvað einkennir góðan tónlistarkennara er mikilvægt að hugsa fyrst og fremst um parfir nemendanna og að við spyrjum okkur hvernig kennara nemendur verðskuldi að fá. Allsup (2016) hvetur til pess að kennarar hugsi tónlistarkennslu á opnari hátt pegar peir skilgreina pá sérfræðipekkingu sem tónlistarkennari parf að hafa. Par gegna tónlistarháskólar sem mennta tónlistarkennara framtîđarinnar lykilhlutverki og hvernig peir búa nemendur undir að starfa sem tónlistarkennarar. Undirbúa peir nemendur nógu vel til að starfa sem tónlistarfólk í óvissri framtîð? Mikilvægt er að hugsa um hvernig hægt er að undirbúa nemendur sem best undir tónlistarlífið og pær áskoranir sem peir standa frammi fyrir. Petta eru spurningar sem varða samfélagið í heild, líkt og flestar spurningar sem varða menntun og menntakerfi. Samfélagið fjárfestir í menntun og leggur mikið traust á hendur menntastofnunum sínum (Allsup, 2015, 2016; Hausman, 2009; Jorgensen, 2003).

Hvað einkennir pá góða tónlistarkennslu? Ekki er óalgengt að pessari spurningu sé svarað með slagorðum á borð við framúrskarandi árangur, afköst, afburðanemanda o.s.frv. (Hausman, 2009; 
Reimer, 2003). Í stað pess væri áhugaverðara að nálgast pessa spurningu á heimspekilegri hátt og spyrja sig hvort ekki sé mikilvægara að skoða gildismat okkar. Hvert er markmið menntunarinnar, eftir hvaða gildum vinnum við, hverju skilar menntunin og fyrir hvern? Ekki er síður mikilvægt að hugsa um hvort hún skili á endanum betri manneskjum, tónlistarlífi og samfélagi (Allsup, 2015, 2016; Jorgensen, 2003).

\section{Hinn sjálfskapaði kennari og meistari}

Elliott og Silverman (2015) fjalla um hversu útbreidd sú hugmynd er að góður hljóðfæraleikari sé sjálfkrafa góður kennari, eða að nóg sé að búa yfir góðri hæfni á ákveðið hljóðfæri til pess að geta kennt á pað. Í framhaldinu leggja pau mikla áherslu á að kennarar staldri við, hugsi um hvers eðlis tónlistarkennsla er og rýni í eigin kennsluaðferðir með gagnrýnu hugarfari. Hann hvetur kennara til að hugsa til baka og fara yfir hvað skipti mestu máli í peirra eigin tónlistarnámi (Elliott og Silverman, 2015). Flestir kannast við kennara sem eru vissulega afburða tónlistarfólk en hafa annaðhvort lítinn áhuga á kennslu eða eiga erfitt með að miðla pekkingu sinni og færni áfram til nemenda sinna. Margir reyna að fá nemendur til pess að herma eftir sínum persónulega stíl í stað pess að aðstoða pá við að próa sinn eigin stíl og styðja pá í að vaxa sem sjálfstætt tónlistarfólk. Að mati Elliott og Silverman eru pað mikil mistök í fari kennara en ástæðan fyrir pessu getur verið takmörkuð pekking og yfirsýn peirra á kennsluaðferðir og leiðir til að laða fram pað besta hjá nemendum sínum. Pá er auðvelt að grípa til pess ráðs að kenna á nákvæmlega sama hátt og kennarinn sjálfur lærði, en ólíklegt er að pað leiði til árangurs að nota sömu aðferð hjá öllum par sem nemendur eru eins ólíkir og peir eru margir (Elliott og Silverman, 2015). Einnig er ósennilegt að kennari sem beitir pessum aðferðum nái til fjölbreytts nemendahóps og taki mið af pörfum hvers og eins, og algengt er að tónlistarkennslan verði nemendum frekar byrði en að hún viðhaldi spilagleði peirra og ástríðu fyrir faginu.

Elliott og Silverman vara tónlistarkennara jafnframt við pví að setja sjálfa sig í forgrunn í kennslunni, og benda á að nemandinn verði alltaf að vera í fyrsta sæti og að megináherslan verði að vera á proska hans og menntun. Par megi ekki vanmeta pekkingu á kennslufræði og listinni að kenna og hafa að markmiði að ná fram pví besta hjá nemandanum með ólíkum kennsluaðferðum. Pað sé ekki síður mikilvægt en færni kennarans sem hljóðfæraleikara. Pau færa rök fyrir pví að góður hljóðfærakennari verði bæði að hafa góða leikni á hljóðfæri sitt og djúpa pekkingu á kennslufræði tónlistar (Elliott og Silverman, 2015). Enn fremur benda pau á að til pess að kenna purfi annars konar hæfni og skilning en til pess að koma fram og flytja tónlist, en par sé mannlegur skilningur og hæfileikinn til pess að miðla tónlistinni áfram til nemenda mjög mikilvægur, sem og fræðileg greining á viðfangsefninu. Lykilatriði er að pað sama virkar ekki fyrir alla í tónlistarkennslu og einstaklingur verður pví að hafa góða yfirsýn yfir ólíkar kennsluaðferðir, sem og djúpa ástríðu fyrir og pekkingu á faginu til pess að verða góður kennari (Elliott og Silverman, 2015). Í pessu samhengi er áhugavert að á undanförnum árum hafa sífellt fleiri tónlistarháskólar bætt kennslufræðiáföngum inn í námsleiðir sínar par sem annars er einkum lögð áhersla á hljóðfæraleik eða söng. Рað er mjög jákvæð próun og hlýtur að styrkja hljóðfæraleikarann sem kennara og listamann að fá kennslufræðimenntun (Daniel og Parkes, 2017).

\section{Listamaðurinn sem kennari og kennarinn sem listamaður}

Í bók sinni A Philosophy of Music Education (2003) fjallar tónlistarfræðingurinn Bennett Reimer um eðli listarinnar og tónlistarkennslu. Hann lýsir pví lærdóms- og proskaferli sem tónlistarmenn purfa að ganga í gegnum allan sinn feril. Gagnlegt er að skoða hvernig hann skrifar um tónlistarkennslu en hann lítur svo á að kennarinn og flytjandinn séu í raun og veru tvær hliðar á sama starfi. Kennslan og lærdómurinn séu svo stór hluti af faginu að hann verði ekki skilinn frá tónlistariðkun eða pví að vera listamaður. Раð að kenna tónlist geri hljóðfæraleikara að betri listamönnum og fái pá til að kafa dýpra í merkingu listarinnar. Einnig fjallar hann um hvernig kennslan styrkir listamanninn og hjálpar honum í lærdómsferli sínu. Til pess að geta miðlað listinni áfram á innihaldsríkan og áhugaverðan 
hátt purfa kennarar að hafa djúpan skilning á listinni sem peir iðka. Ekki sỉður purfa peir að búa yfir mannlegu innsæi og skilningi til pess að ná til nemenda og hreyfa við peim (Reimer, 2003). Reimer heldur pví jafnframt fram að til pess að skilgreina verðmæti eða gildi tónlistarmenntunar verði að skilgreina gildi listarinnar sjálfrar pví pað sé eitt og hið sama. Til pess að verða góðir kennarar verði tónlistarmenn að leitast við að fanga kjarna listarinnar og miðla honum áfram. Hann vill pví nálgast menntunarfræði tónlistar á heimspekilegan hátt og spyr fagurfræðilegra spurninga um dýpri merkingu listarinnar sjálfrar (Reimer, 2003).

Jerome Hausman (2009) hefur einnig rannsakað listina að kenna og í skrifum hans koma fram svipaðar hugmyndir um listamanninn sem kennara. Hann fjallar meðal annars um pað skapandi ferli sem kennari í listum á efri skólastigum fer í gegnum með nemendum sínum og leggur ríka áherslu á mikilvægi reynslu hans af pví að starfa sem listamaður. Hann álítur að sú innsýn í listheiminn og skilningur sem af pví hljótist sé ómissandi í allri listkennslu. Listgreinakennari verði að standa styrkum fótum í greininni og vita um hvað pað snýst að starfa við fagið til pess að geta kennt og miðlað af sinni pekkingu. Víða í öðrum menningarheimum sé ekki talað um kennara í listgreinum, en miklu frekar um að meistarar taki að sér sveina eða aðstoðarmenn sem læri svo fagið af peim. Par sé ekki skilið á milli listamanns og kennara heldur sé pað ein og sama manneskjan. Litið sé svo á að kennsla og flutningur séu tvær órjúfanlegar hliðar á að vera listamaður. Hér á hann ekki við að allir listamenn séu ósjálfrátt góðir kennarar, heldur undirstrikar Hausman hversu mikilvægt sé að greina hvaða eiginleika og pekkingu listamaðurinn purfi að hafa til pess að geta orðið góður kennari. Einnig segir hann að góðir kennarar purfi að búa yfir listfengi og vera vel heima í sínu fagi (Hausman, 1967, 2009). Líkt og Reimer (2003) fjallar hann um gildi pess að greina kjarna listarinnar og hvernig hann sé hinn sami, hvort sem rætt er um listkennslu eða listina sjálfa. Hann leggur jafnframt ríka áherslu á hversu mikilvægir listgreinakennarar geta verið í lífi nemenda sinna og góður kennari haft mikil áhrif á nemendur. Pannig hvetur hann kennara til pess að vanmeta ekki pað vald heldur nota pað til góðs. Peir purfi að hugsa um hverju peir vilji ná fram og með hvaða aðferðum. Í pví felst að spyrja sig spurninga líkt og „hvernig viltu miðla áfram pínum hugmyndum og kenna nemendum staðgóða tækni?“ og „hvernig hefur pú jákvæð áhrif á gildismat og viðhorf nemenda?“ (Hausman, 1967, 2009).

\section{Breytingar með mennskuna að vopni}

Í pessu samhengi er áhugavert að skoða hugmyndir Estelle R. Jorgensen, en í bók sinni Transforming Music Education (2003) spyr hún áleitinna spurninga á borð við pá hvaða áhrif við viljum að tónlistarmenntun hafi á nemendurna sem hennar njóta, nærsamfélagið, skólakerfið og samfélagið í heild. Pað er ekkert eitt rétt svar við pessari spurningu en hún hvetur tónlistarkennara til pess að líta í eigin barm og gefa pví gaum hvernig peir hugsa um tónlist og tónlistarmenntun. Hún fjallar um hve miklu máli mannlegi pátturinn skipti í menntuninni og hvernig neikvæð upplifun tónlistarnema í skólagöngunni seytli út í tónlistarlífið og hafi eitrandi áhrif á samfélagið og líðan tónlistarfólks. Jorgensen hvetur til pess að kennarar flétti inn í kennsluaðferðir sínar hugsun sem hvílir á jafnrétti, sanngirni og samkennd. Pannig eigi markmið kennslunnar að snúa að dýpkun mannlegs skilnings og vinna að pví góða og fagra (Jorgensen, 2003). Með pessi gildi að leiðarljósi megi endurhugsa kennsluhætti og breyta upplifun nemenda. Slíkt telur Jorgensen að myndi stuðla að betra tónlistarlífi með heilbrigðari samskiptum manna á milli. Pessar hugmyndir útfærir hún enn frekar í bók sinni The Art of Teaching Music (2008).

Slíkar breytingar á hugsunarhætti krefjast pess að tónlistarkennarar geri miklar kröfur til sjálfs sín, samstarfsfólks síns og nemendanna um vönduð samskipti og vinnubrögð sem einkennast af virðingu fyrir manneskjunni og viðfangsefnum kennslunnar. Ef vilji er til að breyta tónlistarmenntun til hins betra og raunverulega takast á við pau mein sem fyrirfinnast í menntakerfinu verða tónlistarkennarar að brjótast út úr daglegri rútínu og endurskoða kerfi og valdastrúktúra sem eiga sér djúpar rætur í samfélaginu. Pað er áskorun að endurskoða námskrár á pann hátt að tekið sé tillit til mannlegra pátta og að kennari geti komið til móts við hvern nemanda á hans forsendum með pví að leita nýrra og skapandi leiða við kennsluna. Hér er ekki átt við að gefa eigi eftir í faglegum kröfum 
heldur að vinna að pví á sama tíma að viðhalda neistanum og að veita nemandanum djúpa og innihaldsríka tónlistarmenntun (Jorgensen, 2003). Jorgensen kallar eftir byltingu í tónlistarmenntun með mennskuna að vopni og vill með pví breyta tónlistarlífinu í heild sinni og gera pað betra og manneskjulegra. Hún varar við pví að líta á óbreytt menntakerfi sem náttúrulögmál og hvetur til pess að unnið sé stöðugt að pví að bæta pað svo par sé ekki aðeins pláss fyrir fáa útvalda heldur rými fyrir ólíkar leiðir sem henti ólíkum nemendum (Jorgensen, 2003, 2008).

Flestir peir nemendur sem halda áfram tónlistarnámi á framhalds- og háskólastigi hafa að jafnaði gert pað af einlægum áhuga og gleði af tónlistarflutningi. Pað er pví gríðarlega mikilvægt að nálgast nemendur á jafningjagrundvelli par sem kennari vinnur með nemandanum, hvetur hann til dáða og opnar fyrir honum dyr inn í ólíka heima tónlistarinnar í stað pess að torvelda peim inngöngu í „helgidóminn“ (Allsup, 2016). Menntun verður að snúast um nemandann, hvernig tónlistarmenn og manneskjur við viljum ala upp en ekki síst hvernig tónlistarsamfélag við viljum byggja upp í sameiningu (Jorgensen, 2003).

Elliott og Silverman taka í sama streng, en í bókinni Music Matters (2015) er peim hugleikið hvað getur miður farið í kennslustofunni pegar tónlist er kennd í einkatímum. Pau telja að kennarar gangi oft allt of langt í ofurnákvæmni á kostnað músíkalskrar hugsunar og spilagleði nemendanna. Megináherslan sé oft á tíðum frekar lögð á minnstu tæknilegu smáatriði frekar en á að nemendurnir geti blómstrað sem tónlistarmenn og manneskjur. Pau halda pví fram að pessi nálgun sé mjög takmarkandi og að raunveruleg tónlistarmenntun verði að miða að pví að opna augu nemandans og aðstoða hann í lærdóms- og proskaferli sínu. Pó að staðgóð tæknikennsla sé einnig mikilvæg pá verði líka að hefja sig yfir smáatriðin, leita dýpri merkingar og tónlistarlegs skilnings (Elliott og Silverman, 2015). Til pess að hvetja nemendur til dáða í leit sinni að kjarna tónlistarinnar er lykilatriði að viðhalda neistanum og ástríðunni sem í flestum tilfellum varð til pess að peir héldu áfram tónlistarnámi á framhalds- og háskólastigi (Allsup, 2016).

\section{Mannkostamenntun}

Jorgensen og fleiri fræðimönnum er tíðrætt um hverju menntunin skilar til samfélagsins og til einstaklingsins. Spurningin um hvernig menningu við viljum stuðla að og hvernig við undirbúum nemendur á bestan hátt fyrir framtíðina liggur eins og rauður práđur í gegnum pær rannsóknir sem hér hafa verið skoðaðar (Allsup, 2016; Elliott og Silverman, 2015; Jorgensen, 2003, 2008). Í pví samhengi er áhugavert að skoða hugmyndir um mannkostamenntun (e. character education) sem hafa orðið áberandi í menntunarfræðum á sỉðustu árum. Kristján Kristjánsson (2015) hefur fjallað um slíka menntun og mikilvægi pess að huga að pví að nálgast kennslu ólíkra greina út frá ákveðnum dyggðum með pað að markmiði að mennta heiðarlega og réttláta einstaklinga sem hafa allar forsendur til að lifa góðu lífi og leggja sitt af mörkum til samfélagsins. Í pessum hugmyndum um mannkostamenntun er fjallað um menntandi eiginleika listarinnar á áhugaverðan hátt, pað er hvernig listmenntun getur fært okkur dýpri skilning á samfélaginu, sögunni og manneskjunni og einnig hvernig listgreinakennsla gegnir mikilvægu hlutverki í almennri menntun. Pessar hugmyndir próast á grunni dyggðasiðfræði og má rekja allt aftur til hugmynda Aristótelesar (Ingimar Ólafsson Waage, 2018; Kristján Kristjánsson, 2015). Listirnar eru nátengdar tilfinningalífi mannsins, geta jafnframt tekið á málefnum samfélagsins og verið vettvangur samræðu og skoðanaskipta. Listaverk geta einnig veitt okkur siðferðilega pekkingu, veitt mönnum dýpri sjálfsvitund og hjálpað fólki að skilja hlutskipti annarra (Ingimar Ólafsson Waage, 2018). Í hugmyndum um mannkostamenntun í skólastarfi er lögð áhersla á dyggðir á borð við heiðarleika, réttlæti og góðvild og pau gildi fléttuð inn í kennslu ólíkra námsgreina. Markmiðið með pessu er bæði að stuðla að andlegum proska nemenda og að peir geti lifað góðu og innihaldsríku lífi (Kristján Kristjánsson, 2015).

Fáar námsgreinar ættu að vera betur til pess fallnar en tónlist að flétta pessi gildi inn í námið, par sem viðfangsefnið er svo oft sammannlegar tilfinningar. Til pess að gera tónverkin að sínum verður flytjandinn að geta sett sig inn í huga höfundar og gert pær tilfinningar sem verkið ber í sér að sínum. 
Í tónlistarnámi er skilningur á sögu og samfélagi jafnframt mjög mikilvægur til pess að átta sig á pví upp úr hvaða bakgrunni verkin verða til og til pess að dýpka skilning á tónlistinni og túlkun hennar. Pess vegna ætti mannkostamenntun að vera áhugaverð og fýsileg nálgun fyrir tónlistarkennara með pað að markmiði að stuðla að bættri menntun og heilbrigðara tónlistarsamfélagi (Elliott, Silverman og Bowman, 2016; Jorgensen, 2008).

\section{Jákvætt skólaumhverfi}

Allsup fjallar um hversu mikilvægt pað er, bæði fyrir listamenn og tónlistarlífið í heild, að breyta aðferðum og hegðunarmynstrum í einkatímum, pví par leynist oft ofbeldi sem sé orðið normalíserað í samfélaginu (Allsup, 2016). Рað er pví gríðarlega mikilvægt að samfélag tónlistarmanna og kennara taki höndum saman og vinni að pví að græða pau sár sem pessar kennsluaðferðir hafa skilið eftir hjá einstaklingum og í tónlistarlífinu í heild. Í pví samhengi er mikilvægt að kennarar hugsi um pau flóknu mannlegu samskipti sem fara fram í kennslustofunni og hvernig samskipti peir vilja að nemendur tileinki sér. Fyrsta skrefið í átt að heilbrigðu og réttlátu tónlistarsamfélagi, sem er laust við valdbeitingu, er að sjá til pess að samskipti nemenda og kennara einkennist af virðingu fyrir hver öðrum og viðfangsefninu, enda muni pað skila sér beint út í tónlistarlífið og samfélagið (Allsup, 2016; Bowman, 2010; Elliott og Silverman, 2015; Elliott o.fl., 2016).

Pað er umhugsunarefni hversu mikilvægt pað er að skapa aðstæður fyrir nemendur til að proskast og uppgötva galdur listarinnar í næði. Af peim sökum parf að skapa skólaumhverfi par sem lærdómsferlið sjálft er ánægjulegt og innihaldsríkt. Рað er pví lykilatriði að skólastjórnendur vinni að pví skapa skólaumhverfi sem er styðjandi og par sem nemendur og kennarar geta notið gleðinnar við að iðka listina. Í slíku umhverfi geta menn gert mistök, orðið fyrir vonbrigðum og fengið uppbyggilega gagnrýni í öruggu umhverfi. Vinna verður að pví að skapa skólasamfélag par sem nemendur geta vaxið sem manneskjur og listamenn, fundið styrk sinn og lært að yfirstíga veikleika sína á námsárunum (Hausman, 1967, 2009; Jorgensen, 2003; Reimer, 2003).

Í pessu samhengi er áhugavert að skoða hugmyndir um faglegt lærdómssamfélag (e. professional learning community). Styrking lærdómssamfélags hefur reynst árangursrík leið til að auðvelda og styrkja starfspróun kennara. Í pví felst að greina og meta eigin starfshætti og í framhaldinu að leita allra leiða til að bæta pá - og par með gæði námsins og árangur nemenda. Sameiginlegt markmið peirra verður að bæta skólann í heild sinni og veita nemendum eins góða menntun og kostur er. Hér er lykilatriði að stjórnendur og kennarar vinni saman að pví að móta sameiginlega framtíðarsýn (Anna Kristín Sigurðardóttir, 2013; Bolam, o.fl., 2005; Hord og Hirsh, 2009).

Pegar stefnt er að pví að vinna að umbótum á starfsemi tónlistarskóla og að próa lærdómssamfélag er mikilvægt að gera sér grein fyrir hvert markmiðð er og hver ávinningurinn verður fyrir skólastarfið. Lærdómssamfélagið er í raun og veru ákveðin ríkjandi menning í skólastarfinu, sem hvetur kennara og starfsmenn stöðugt til að mennta sig og leita allra leita til að bæta kennsluhætti sína og pekkingu (Fullan, 2016). Í pessari skólamenningu ríkir sú sameiginlega sýn meðal kennara, starfsfólks og skólastjórnenda að pau séu í stöðugri pekkingarleit með pað að meginmarkmiði að styrkja og bæta nám sinna nemenda. Árangur nemenda og gæði pess náms sem peir njóta er ætíð pað sem skiptir mestu máli í faglegu lærdómssamfélagi og allra leiða er leitað til pess að bæta námið og styðja við nemendur. Pá er bæði leitað fanga innan skóla og utan og til að pess konar hugsunarháttur geti orðið útbreiddur meðal kennara verður að fara fram ákveðin sjálfsgagnrýni og greining á hvað megi bæta í eigin starfs- og kennsluháttum (Fullan, 2016; Stoll, o.fl., 2006).

Ef við spyrjum okkur hver séu meginmarkmið og tilgangur alls skólastarfs hlýtur svarið alltaf að vera hvað námið sjálft og skólavistin skilur eftir sig hjá nemendum og hvaða áhrif hún hefur á proska peirra og menntun. Pví hlýtur lykilspurningin að vera: Hvernig undirbúum við nemendur á sem bestan hátt undir tónlistarlífið og styrkjum pá sem manneskjur? Par er bæði átt við faglegan undirbúning undir frekara nám og störf en líka að peir geti orðið virkir pátttakendur í samfélaginu 
og lifað innihaldsríku lífi. Pegar við hugsum um kjarnastarfsemi tónlistarskóla og hvernig megi hlúa vel að henni hljóta umbæturnar að snúast um gæði kennslunnar og að stöðugt sé verið að leita leiða til að bæta hana - og par með menntun nemendanna. Raunverulegt lærdómssamfélag styður við alla pessa pætti (Hord og Hirsh, 2009).

\section{Framtíðarsýn: Virðing án ótta}

Pað er umhugsunarvert hve margir af fremstu fræðimönnum á sviði menntunarfræði tónlistar gera pá óvægni sem oft viðgengst í tónlistarnámi að umfjöllunarefni. Margir af peim höfundum sem hér hefur verið fjallað um hafa lýst pungum áhyggjum af valdaójafnvægi sem skapast getur í einkakennslu í hljóðfæraleik eða söng og afleiðingum pess. İ mörgum af peim rannsóknum sem hér voru skoðaðar var sterk krafa um breytingar, og ekki síst var kallað eftir breyttum samskiptamynstrum í kennslu. Pað verður áskorun fyrir tónlistarheiminn að færa sig nær nútímanum og stuðla að viðurkenndum kennsluaðferðum sem byggja á niðurstöðum rannsókna. Pað er augljóst að viðteknar hefðir í tónlistarnámi standast ekki alltaf kröfur samtímans um gæði og kennslufræðilega nálgun. Aukin pekking á menntunarfræði og fjölbreyttum kennsluaðferðum myndi örugglega bæta kennsluna og koma í veg fyrir mistök sem algeng eru í hljóðfærakennslu. Par er lykilatriði að vinna gegn peim niðurbrjótandi samskiptum og valdbeitingu sem oft fer fram í tónlistartímum og pá ekki síst í einkatímum fyrir luktum dyrum.

Pegar litið er yfir pessar ólíku rannsóknir má greina sameiginlega grunnhugsun í peim tillögum sem komu fram í peim um umbætur í tónlistarnámi. Hún er sú að nemandinn sé í miðpunkti og komið sé til móts við parfir hans og áhuga. Einnig eigi kennslan að vera sniðin að pörfum og markmiðum hvers nemanda, og par sem um einkatíma er að ræða ætti að vera hægt að bjóða upp á mjög einstaklingsmiðað nám par sem nemendum er veitt mikil athygli og peir fá stuðning frá kennurum sínum. Pað er nokkuð kaldranalegt að átta sig á pví að gagnrýnin á einkakennsluformið gefur í skyn að bæði kennarinn og utanaðkomandi markmið eins og tónleikar og próf hafi gjarnan meira vægi í námsferlinu en nemandinn sjálfur. Einkakennsluformið ætti einmitt að bjóða upp á að námið væri sniðið að pörfum og markmiðum hvers nemanda. Mikilvægt er pví að kennsla sé nemendamiðuð frekar en kennaramiðuð og að nemandinn taki virkan pátt í náminu. Kennari parf að hvetja til sjálfstæðrar og skapandi vinnu nemandans og ýta undir frumkvæði með pað fyrir augum að mennta sterka og sjálfstæða einstaklinga sem geta fótað sig í tónlistarlífinu í ófyrirséðri framtíð. Nemendur verða að fá ómældan stuðning í náminu og pví parf proska- og lærdómsferli nemandans að verða aðalatriði kennslunnar. Рað má segja að bættir kennsluhættir feli pá í sér að nemandinn sjálfur og hans glíma við tónlistararfinn verði í forgrunni en ekki tónlistararfurinn einn og sér. Góður kennari parf að horfa fyrst og fremst á nám og velferð nemandans en aðlaga aðferðir og utanaðkomandi lokamarkmið með hag nemandans að leiðarljósi.

Í pessu augnamiði er nauðsynlegt að kennarar gefi sér tíma til pess að ígrunda eigin kennsluaðferðir, til dæmis með námi á sviði menntunarfræða tónlistar, með pví að greina og gagnrýna aðferðir sínar og skoða hverjar peirra skila mestu til nemandans. Til pess að pað sé mögulegt er mikilvægt að tónlistarskólar styðji við bakið á kennurum og gefi peim pað svigrúm sem nauðsynlegt er til endurmenntunar. Ekki er síður mikilvægt að háskólar bjóði upp á áhugaverðar og vel uppbyggðar námsleiðir í menntunarfræði tónlistar, bæði til að mennta nýja kynslóð tónlistarkennara og par sem starfandi kennarar geta dýpkað skilning á tónlistarnámi og tónlistarmenntun. Pað er verðugt verkefni tónlistarskóla, ekki síst á efri stigum og í háskóla, að skapa lærdómssamfélag par sem jákvæð lærdómsmenning ríkir hjá nemendum og kennurum. Pví ætti markmiðið að vera að móta skólasamfélag par sem nemendur og kennarar geta vaxið sem manneskjur og listamenn og að lærdómsferlið sjálft sé ánægjulegt og innihaldsríkt.

Í pví samhengi er mikilvægt að sú spurning hvernig tónlistarmenn og manneskjur við viljum ala upp sé í forgrunni á sama tíma og við hugsum um hvernig tónlistarsamfélag við viljum byggja upp. Breyttur hugsunarháttur og frampróun kennsluhátta ætti að geta skilað umtalsverðum ávinningi fyrir nemendur, kennara og listasamfélagið í heild. Mannúðlegri nálgun og mannkostamenntun 
myndi ýta undir menningarlega grósku, sköpun og velferð. Ef hugsun jafnréttis, mannúðar og samkenndar fléttaðist inn í tónlistarnám í auknum mæli gæti pað stuðlað að betri samskiptum og bættri líðan peirra sem starfa í tónlistarlífinu.

\section{Íslenskt samhengi}

Í greininni hefur verið fjallað um gagnrýnin skrif erlends fræðafólks á fyrirkomulag og hefðir í tónlistarmenntun par sem pað pekkir best til. Lesendur gætu pví spurt sig hvort sama gagnrýni eigi erindi við íslenskt skólakerfi og tónlistarlíf. Greinarhöfundar telja sig pekkja ágætlega til viðtekinna kennsluhátta og fyrirkomulags tónlistarnáms á Íslandi og sjá pörf fyrir alveg sömu brýningu gagnvart tónlistarmenntun hér á landi og finnast í erlendum fræðaskrifum. Einkakennslufyrirkomulagið er nokkuð ráðandi í íslenskum tónlistarskólum eins og fram kemur í greininni og er jafnvel algengara á yngri stigum hér á landi en víða erlendis. Enn fremur glíma íslenskir hljóðfæraleikarar ekki síður við álagskvilla en erlend starfssystkini sbr. rannsókn Ingunnar Jónsdóttur (2015). Рað er pví líklegt að endurskoða megi áherslur í menntun tónlistarfólks og tónlistarkennara hérlendis og í pví augnamiði sannarlega mikilvægt að hlúa að frekari rannsóknum og próun á sviði tónlistarmenntunar á Îslandi.

\section{Awesome respect or respectful awe? On conventional practices in music teaching and learning}

In this article, scholarly writings on conventions and traditions in music education are explored. The purpose is to shed a critical light on current practices in music teaching and learning and it is pointed out, that remarkably little has been written in terms of critique or questioning of the status quo in Icelandic music education. The focus of the article is mostly on music teaching and learning at higher levels of music studies where students are taking private lessons with a master tutor on a musical instrument, including the voice. Severe side effects that can impact professional musicians for life have been known to result from conventional teaching practices at higher levels of music education. This writing is rooted in a desire to search for a positive and healthy learning environment where music students and teachers can grow concurrently as human beings and as artists. The harmful effects of negative or toxic learning environments in music schools can eventually lead to serious consequences for individuals and professional careers.

The article begins with a summary of the traditional private-studio and master-apprentice approaches in music education, outlining how these models developed and became the standard in serious or elite music learning in the Western tradition of music education. Then, a discussion follows on the power structures at play in these learning situations and what the consequences can be for individuals and communities. Furthermore, attention is directed towards conventional learning cultures in higher music education and which strategies could be taken towards more democratic and humane approaches to music teaching and learning at the upper levels of music study. The focus of the discussion is directed towards the choices teachers can make and how the learning environment can support the healthy development of individuals within music education institutions. In this context, the ideas of character education within educational reform are explored.

Critical theories in music education have investigated conventions and traditions in music teaching and learning and pointed out how power structures in the conventional masterapprentice model can be detrimental to the education and formation of musicians. An overview is provided of several scholarly writings on the philosophy of music education from this perspective. Most of the scholars cited have in common that they build on Critical Theories in their approach to music education with strong references to Dewey and Freire in their view on educational reform. 
It is imperative that music teachers and music education institutions ask critical questions regarding their role in the education of their students, such as whether it is their role to uphold conventions and traditions handed down for centuries, or whether their duty is to search for new ways to instruct individuals who are allowed to influence their own learning processes. In order to foster progress in music education at any level it is necessary to build education systems that will train individuals to develop and take an active role in their own learning processes. A large number of professional musicians suffer from challenging working conditions that affect their mental and physical health. Professional musicians are known to treat side effects of their careers such as performance anxiety and depression with prescription drugs to a much higher extent than in the normal population. There is more than one possible cause of this problem but many scholars point towards the culture and traditions surrounding the educational systems where musicians are schooled. These traditions are discussed as well as what actions can be taken to change conventional practices in music schools.

It is stated that private lessons or the master-apprentice model seems to be the dominant model in Icelandic music schools and even more prominent in the early stages of music studies in Iceland than in many other countries. However, more research is needed on teaching practices in Icelandic music schools. Public or scholarly discussion of methods, conventions and practices in Icelandic music schools has been minimal to this date. Debates in the field of music education at international level in the past decades have seemingly gone more or less unnoticed in the Icelandic music education community. As this article provides a review of some of the scholarly critiques within music education at international level, the authors hope that it will encourage a lively debate and an increased awareness of issues in music education within Iceland and in a wider context of reform in music training and instruction.

Key words: Music education, teaching, master-apprentice, private-teaching, powerbalance, educational policy

\section{Um höfunda}

Helga Rut Guðmundsdóttir (helgarut@hi.is) er prófessor í tónlistarfræðum við Menntavísindasvið Háskóla Íslands. Hún kennir námskeið á sviði tónlistarmenntunar í kennaranámi á öllum skólastigum og kennir aðferðir og kenningar um tónlistarproska og tónlistarnám. Rannsóknir hennar spanna allt frá nótnalestri og tónlistarskynjun til rannsókna á fyrirkomulagi tónlistarnáms. Ritrýnt efni eftir hana er birt í helstu útgáfum á sviði tónlistarmenntunar og tónlistarsálfræði.

Freyja Gunnlaugsdóttir (freyja@menton.is) er skólameistari Menntaskóla í tónlist. Freyja er klarínettuleikari að mennt og lauk Konzertexamen, æðstu gráðu í hljóðfæraleik frá Hochschule fur Musik Hanns Eisler í Berlín. Hún hefur jafnframt lokið meistaraprófi í stjórnun og stefnumótun frá Háskóla Íslands og viðbótardiplóma í kennslufræði frá Menntavísindasviði HÍ. Freyja starfaði um árabil sem hljóðfæraleikari, lengst af í Pýskalandi. Hún hefur umfangsmikla reynslu af hljóðfærakennslu og skólapróun á sviði tónlistarkennslu.

\section{About the authors}

Helga Rut Gudmundsdottir (helgarut@hi.is) is a Professor of Music Education at the University of Iceland, School of Education. She teaches music pedagogy at all levels of teacher education and teaches methods and theories in music development and education. Her research ranges from music reading and music perception to studies on 
music education in Iceland. Helga's writings are published in prominent peer-reviewed publications in music education and music psychology.

Freyja Gunnlaugsdóttir(freyja@menton.is) is Principal at the Reykjavík College of Music. Freyja is a clarinettist and has performed with several orchestras and chamber music groups throughout Europe. She graduated with Konzertexamen from Hochschule für Musik Hanns Eisler Berlin. Later she completed a master's degree in strategic management and an additional postgraduate diploma in upper secondary school teaching from The University of Iceland. Freyja has taught the clarinet at all school levels.

\section{Heimildir}

Ackerman, B., Driscoll, T., \& Kenny, D. T. (2012). Muscolosketel Pain and Injury in Professional Orchestral Musician in Australia. Medical Problems of Performing Artists, 181-187.

Allsup, R. E. (2015). Music teacher quality and the problem of routine expertise. Philosophy of Music Education Review, 23(1), 5-24.

Allsup, R. E. (2016). Remixing the classroom: Toward an open philosophy of music education. Bloomington: Indiana University Press.

Anna Kristín Sigurðardóttir. (2013). Skóli sem lærdómssamfélag. Í Rúnar Sigpórsson, Rósa Eggertsdóttir og Guðmundur Heiðar Frímannsson (ritstjórar), Fagmennska i skólastarf: Skrifað til heiðurs Trausta Porsteinssyni (bls. 35-53). Reykjavík: Háskólinn á Akureyri og Háskólaútgáfan.

Arthur, J., Kristjánsson, K., Harrison, T., Sanderse, W. og Wright, D. (2017). Teaching character and virtue in schools. London: Routledge.

Bolam, R., McMahon, A., Stoll, L., Thomas, S. og Wallace, M. (2005). Creating and sustaining professional learning communities. Research Report Number 637. London: General Teaching Council for England, Department for Education and Skills.

Bowman, W. (2010). Envisioning the impossible. Action, Criticism, and Theory for Music Education, 9(3), 1-7. http://act.maydaygroup.org/articles/Bowman9_3.pdf

Brandfonbrener, A. G. (2009). History of playing-related pain in 330 university freshman music students. Medical Problems of Performing Artists. 24(1), 30-36.

Brodsky, W. (1996). Music performance anxiety reconceptualized. Medical Problems of Performing Artists, 11(3), 88-98.

Burwell, K. (2013). Apprenticeship in music: A contextual study for instrumental teaching and learning. International Journal of Music Education, 31(3), 276-291. https://doi.org/10.1177/0255761411434501

Carey, G. og Grant, C. (2015). Teacher and student perspectives on one-to-one pedagogy: Practices and possibilities. British Journal of Music Education, 32(1), 5-22.

Christophersen, C. (2013). Perspectives on the dynamics of power within collaborative learning in higher music education. Í H. Gaunt og H. Westerlund (ritstjórar), Collaborative learning in higher music education, 77-85. London: Routledge.

Daniel, R. og Parkes, K. A. (2017). Music instrument teachers in higher education: An investigation of the key influences on how they teach in the studio. International Journal of Teaching and Learning in Higher Education, 29(1), 33-46.

Davidson, J. W. og Jordan, N. (2007). "Private teaching, private learning": An exploration of music instrument learning in the private studio, junior and senior conservatories. Í L. Bresler (ritstjóri), International handbook of research in arts education (bls. 729-754). Dordrecht: Springer.

Dewey, J. (1922). Democracy and education: An introduction to the philosophy of education. New York: Macmillan.

Elliott, D. J. og Silverman, M. (2015). Music matters: A philosophy of music education (2. útgáfa). New York: Oxford University Press. 
Elliott, D., Silverman, M. og Bowman, W. (ritstjórar). (2016). Artistic citizenship: Artistry, social responsibility, and ethical praxis. Oxford University Press.

Freire, P. (1998). Pedagogy of freedom: Ethics, democracy, and civic courage. Lanham: Rowman \& Littlefield.

Fullan, M. (2016). The new meaning of educational change. London: Teachers College Press.

Gaunt, H. (2011). Understanding the one-to-one relationship in instrumental/vocal tuition in higher education: Comparing student and teacher perceptions. British Journal of Music Education, 28(2), 159-179. doi: $10.1017 /$ S0265051711000052

Gleitman, H., Fridlund, A. J. og Reisberg, D. (2003). Psychology (6. útgáfa). Pennsylvania: Norton.

Green, L. (2017). Music education as critical theory and practice: Selected essays. London: Routledge.

Hallam, S. (1998). Instrumental teaching: A practical guide to better teaching and learning. Oxford: Heinemann Educational.

Hausman, J. (1967). Teacher as artist \& artist as teacher. Art Education, 20(4), 13-17. doi:10.2307/3190907

Hausman, J. (2009). Art education in higher education: A personal view. Visual Arts Research, 35(1), 106-113. Sótt af http://www.jstor.org/stable/20715491

Hays, K. F. og Brown, Jr., C. H. (2004). You're on: Consulting for peak performance. Washington, DC: American Psychological Association.

Hord, S. og Hirsh, S. (2009). The principal's role in supporting learning communities. Educational Leadership, 66(5), 22-23.

Ingimar Ólafsson Waage. (2018). Grunnpættir menntunar, myndlist og mannkostamenntun. Sérrit Netlu 2018 - Bókmenntir, listir og grunnpattir menntunar. Sótt af http://netla.hi.is/serrit/2018/bokmenntir_listir_menntun/05.pdf

Ingunn Jónsdóttir. (2010). Framkomukvið̇i tónlistarmanna og aðferðir sem peir nota til að vinna bug á honum (óútgefin bakkalárritgerð). Sótt af http://hdl.handle.net/1946/4423

Ingunn Jónsdóttir. (2015). Is music performance anxiety related to social anxiety disorder and self-efficacy? (oútgefin meistararitgerð). Uppsalaháskóli, Uppsalir, Svípjóð.

Jorgensen, E. R. (2003). Transforming music education. Bloomington: Indiana University Press.

Jorgensen, E. R. (2008). The art of teaching music. Indiana University Press.

Kári Árnason, Árni Árnason og Kristín Briem. (2014). Playing-related musculoskeletal disorders among Icelandic music students. Medical Problems of Performing Artists, 29(2), 74-79.

Kenny, D. T. (2006). Music performance anxiety: Origins, phenomenology, assessment and treatment. Context: Journal of Music Research, 31, 51-64.

Kenny, D. T. og Ackermann, B. (2015). Performance-related musculoskeletal pain, depression and music performance anxiety in professional orchestral musicians: A population study. Psychology of Music, 43(1), 43-60.

Kivimaki, M. og Jokinen, M. (1994). Job perceptions and well-being among symphony orchestra musicians: A comparison with other occupational groups. Medical Problems of Performing Artists, 9(3), 73-76.

Kristján Kristjánsson. (2015). Aristotelian character education. London: Routledge.

Kupers, E., van Dijk, M., van Geert, P. og McPherson, G. E. (2015). A mixed-methods approach to studying co-regulation of student autonomy through teacher-student interactions in music lessons. Psychology of Music, 43(3), 333-358. https://doi.org/10.1177/0305735613503180

Lockwood, A. H. (1989). Medical problems of musicians. New England Journal of Medicine, 320(4), 221-227.

Margulis, E. H. (2018). The psychology of music: A very short introduction. Oxford: Oxford University Press.

Persson, R. (1994). Concert musicians as teachers: On good intentions falling short. European Journal for High Ability, 5(1), 79-91.

Reimer, B. (2003). A philosophy of music education: Advancing the vision. New Jersey: Prentice-Hall.

Steptoe, A. (2001). Negative emotions in music making: The problem of performance anxiety. Í P. N. Juslin og J. A. Sloboda (ritstjórar), Music and emotion: Theory and research (bls. 291-307). Oxford: Oxford University Press. 
Stoll, L., Bolam, R., McMahon, A., Wallace, M. og Thomas, S. (2006). Professional learning communities: A review of the literature. Journal of Educational Change, 7(4), 221-258. Sótt af https://link.springer.com/ content/pdf/10.1007\%2Fs10833-006-0001-8.pdfdoi:0.1007/s10833-006-0001-8

Yoshie, M., Kudo, K., Murakoshi, T. og Ohtsuki, T. (2009). Music performance anxiety in skilled pianists: Effects of social-evaluative performance situation on subjective, autonomic, and electromyographic reactions. Experimental Brain Research, 199(2), 117-126.

Póra Einarsdóttir. (2015). Samvinna söngkennara: Nemandinn i forgrunni (óútgefin meistararitgerð). Listaháskóli Íslands, Reykjavík.

Helga Rut Guðmundsdóttir og Freyja Gunnlaugsdóttir. (2021).

Hin óttablandna virðing: Um kennsluhætti og viðteknar hefðir í tónlistarnámi.

Netla - Veftímarit um uppeldi og menntun. Menntavísindasvið Háskóla Íslands.

Sótt af https://netla.hi.is/greinar/2021/alm/05.pdf

DOI: https://doi.org/10.24270/netla.2021.5 